\title{
Location Factors as Moderators between Some Critical Demographic Characteristics and ICT Adoption: A Study of SMEs
}

\author{
Hart O. Awa ${ }^{1, *}$, Bartholomew C. Emecheta ${ }^{1}$, Ojiabo Ukoha ${ }^{2}$ \\ ${ }^{1}$ Department of Marketing, University of Port Harcourt, Nigeria \\ ${ }^{2}$ University of Maryland, Eastern Shore, Princess Anne, USA
}

Copyright $(\mathcal{C} 2015$ by authors, all rights reserved. Authors agree that this article remains permanently open access under the terms of the Creative Commons Attribution License 4.0 International License

\begin{abstract}
The effect of demographic characteristics of management on ICT adoption is well-researched but how such location issues as firm's knowledge centre and diverse workforce explain the interactions between demographic composition of management and the rate of ICT adoption is yet to receive adequate scholarly attention. This forms the cornerstone of this paper. Opinions of 344 SME operators were purposefully sampled across five industries located in three geo-political areas of Nigeria. Two cities (a state capital and a commercial nerve centre) were studied and a four-step hierarchical regression was used to analyze the data. The finding shows that location factors such as availability of diversified workforce and improved knowledge centres statistically influence the age, gender, education, and experience composition of management team and ultimately ICT adoption. Therefore, location factors shape management team's demographics and ICT adoption, and such combination provides SMEs with stronger latitude to be more proactive and pre-emptive in their ICT adoption decision.
\end{abstract}

Keywords ICT, Adoption, Demographics, SMEs

\section{Introduction}

Aside governments and large corporations playing dominant role in the formal economy(37), many economies aggressively pursue public policies that encourage small is beautiful and drive the informal sector through $\operatorname{SMEs}(35$, 34). SMEs stimulate industrialization of any nation as they balance political and economic independence in terms of employment creation, innovation, and flexibility in adapting to changing market demands(40,36). The definitions of SMEs vary amongst economies, regions, and industries but specifically determined by the number of workers, amount of capital invested, annual turnover, size of fixed investment, and sometimes the nature of business or a combination of all [45]. SMEs play significant role in poverty alleviation (especially in developing economies), and the urge to boost success through targeting regional/global markets makes ICT platforms critical in interactive partnerships. The digitalized social platforms within and beyond traditional boundaries exponentially provides SMEs with ample opportunities and plausible agility to diversify socio-economic development and to strengthen competitive advantage (40, 45). Predominantly, literature (e.g., 29, 42, 53) espouse individual difference factors (IDFs) on the recognition that every organization is idiosyncratic. Other more specific studies (e.g., 11, 46) reported on the demographic determinants (e.g., age, experience and functional track, education, and gender) of ICT adoption. Though some of these studies (see 11) show mixed results and some others (see 61) proposed firm's geographical location as ICT adoption driver, none of these studies conceived location as a moderator variable operating between demographic factors and ICT adoption.

This study comes in here because for commercial, cultural, regulatory, and/or other reasons, studies $(1,57)$ show that urban settings provide more attractive business opportunities than rural scenes and that there are different denominations for similar enterprises, and similar denominations for different enterprises. ICT platforms tend to bridge the barriers of geographical location but agglomeration economies still exist especially in Nigeria; the fact is that developmental strides are unevenly distributed across regions and so, adoption opportunities may vary (see classical resources munificence theory). Nigeria's ICT adoption shows a steady growth with online sales approaching N62.4 billion in 2011 against N49.9 billion in 2010 and the expectation is to double the figure by 2014 (56). However, such upward trajectory is rarely sustainable given the narrow focus on upper and middle classes. Reports (e.g., 56) show that aside these classes of people critically domiciling in some cities, their relative small number (when 
compared with low-income earners) seldom gives on-line business a boost in Nigeria. Therefore, this study attempts to unveil if the interaction between the demographics of management team and ICT adoption may be explained by differences in such location indicators as availability of diverse workforce and knowledge centres. This objective is made hold by addressing the following hypothesized relationships.

$\mathrm{H} 1$ : There is a significant relationship between the ages of top executives and speed of ICT adoption; specifically, the rate of adoption is perceived to be faster amongst younger executives than older executives.

H2: There is a significant relationship between the genders of top executive(s) and the rate of ICT adoption; specifically, the rate of adoption is perceived to be faster amongst male executives than female executives.

H3: There is a significant relationship between top executives' experience and adoption of ICT; specifically, the rate of adoption is perceived to be faster amongst executives with cognate experience than executives without such experience.

H4: There is a significant relationship between the levels of top executives' education and ICT adoption; specifically, adoption rate is perceived to be faster amongst executives with higher education than those with lower education.

\section{Theoretical Development}

ICT refers to an array of digital technologies and devices deployed to create, process, analyze, store, retrieve, and disseminate information within a community (39). It defines an organized communication networks including software, hardware, telecommunications, and information management technologies (3) that flatten organizational hierarchy, and allows for social networking amongst on-line community members. These propositions portray ICT applications as value-added and automated architectures that en-courage inter-firm alignment, transparency, operational agility, and effective interactions between people, businesses, governments, and other stakeholders (49). ICT adoption refers to as the decision to apply and to continually use novel digital platforms $(40,45,35)$. It is a matter of mutual exclusiveness; a choice of one platform precludes the other, particularly if both serve the same or similar purpose (see 30 , $18 ; 59)$.

Several theories provide explanatory lenses to adoption behaviour; prominent amongst them are Innovation Diffusion Theory (IDT) (42), Technology Acceptance Model (TAM) (12, 20), Technology-Organization -Environment(T-O-E)(54), and Decision Maker-Technology -Organization-Environment (D-T-O-E) (53). While most of these theories evolve from the theory of reasoned action and have their principal constructs cross-cutting, each contributes to the underpinning literature of adoption. For instance, T-O-E framework postulates that adoption is influenced by technology development and organization's conditions involving necessary business and organizational reconfiguration shaped by industry environment (55). However, because decision-makers are specific internal organization's properties and adoption of technologies is often driven by economic, social, physical, and technical factors (see 38), T-O-E framework is similar to Rogers' (63), enjoys wide applicability, and underpins many empirical studies (e.g., 26, 24; 53, 63).

Specifically, organization's conditions (one of the elements of T-O-E) underpin this work on the recognition that studies and theories view management's characteristics and supports (22), owners' enthusiasm and growth ambitions (17), CEO's knowledge and characteristics (46), and managers' belief differences (41) as significant adoption predictors of ICT solutions that complement literature. Top management and attitudes towards ICT adoption are often shaped, amongst others, by such demographic factors as age, experience, gender, education, and function-al tracks. Though the predictor variables are well studied, simplistic and seem somewhat superficial in the context of ICT, introducing geographical location as a moderator variable provides potentially unique twist since (to one's self) ICT inquiries seldom sought to use location to explain the critical link between ICT adoption and the demographic composition of top management. 


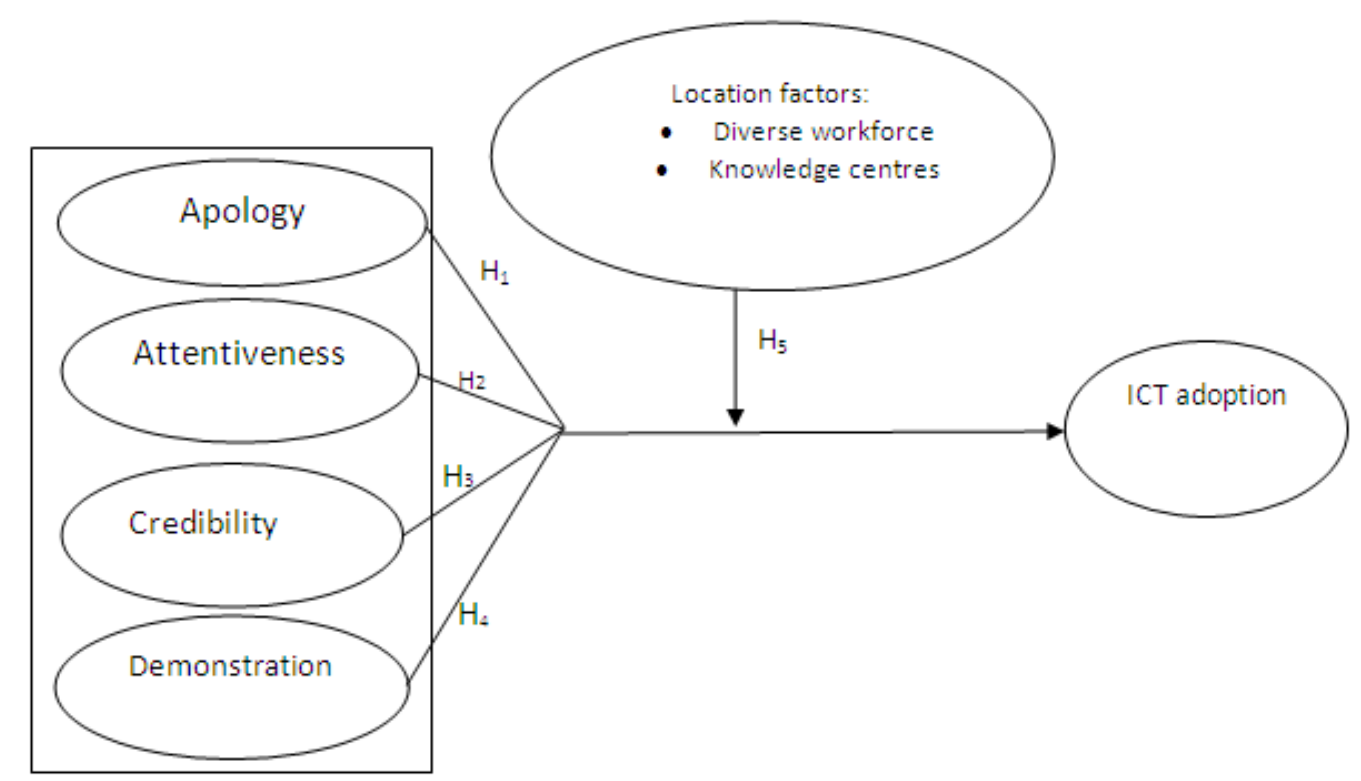

Figure 1. Research framework on direct and moderating effects

\section{Age}

Age measures one's date of birth. Literatures $(24,28)$ establish the generational differences between decision-makers' age and corporate risk-taking behaviour. Younger executives are much more associated with corporate growth (22). The younger the executives the greater their proclivity to take greater advantage of new applications, thus while older executives permit new applications to drive the task (conservative stance); younger executives are increasingly becoming fluent in their language mobility $(13,21)$. Hedges $(24)$ found that the adoption of new devices of mobile phone is evident among executives under 40 , where 73 percent uses the mobile phone as their primary communication tool against 28 percent executives of 50 and above. This has the potential of turning younger executives to device agnostics since they can use the device for many tasks; thus, behaviour is driven less by the available devices rather more by the task at hand $(13,24)$.

Older executives rarely have physical and mental stamina (11) as well as social enablement (48) to grasp novelty; exhibit greater psychological commitments to corporate routines (2); and place premiums on career and financial security (9). Carlsson and Karlsson (7) opine that executives generally avoid any risky actions capable of disrupting their social circles, spending traits, and expectations bordering on retirement benefits.

\section{Gender}

The gender and age of decision-makers influence corporate risk-taking and shape strategic thrusts. Gender shapes human behaviour and managerial decisions (25); it measures the degree of innovation. Studies (20,27, Igbaria et al., 1998 39) show that certain innovation adoption is faster amongst men than women. Gefen and Straub (20) found perceptual differences between males and females in the use of e-mails whereas Jimmie and Mukhopadhyay (27) showed that the relationship between gender and ICT adoption is connected to sex role as females use less computer facilities at home than men. Often early adopters of new technological innovations are predominantly young male executives $(24$, 28). The Germany mobile phones market is 60 percent men and 40 percent women; thus, men spend more time on mobile phones than women (52). This may not be the case in developing nations like Nigeria where many jobless women carry an array of cell-phones and spend over a quarter of the day on phone conversation.

\section{Experience}

Experience is a corporate asset and the best teacher. When consistently acquired, experience impacts on operations and adjustments to market demands, cost structure and learning curves, and employee morale and productivity. Aside other infrastructural resources, lack of internet-use experience and skills hinder adoption $(11,29,19,58,43,11,51)$. Favourable experience in terms of an innovation's simplicity, perceived usefulness, amongst others, influence adoption of similar ones on accounts of affect transfer (see 62,15), categorization theory (see 18), and Thorndike's law of effects (see 54). When experience in ICT intensifies, organizations harness the true potential of technology to improve business processes (32). Hashim (23) proposed that CEO's knowledge has a leaner relationship with how early or late the adoption takes place.

\section{Education}

Executives' levels of professionalism and formal education are significant predictors of ICT adoption $(11,16)$. 
Education affects proactive and/or reactive approaches to rapid technological changes. Although slightly contrary to scholarly (10, Igbaria et al., 1998 53) submission, educational attainment, to a large extent, shapes an individual's value systems, cognitive preferences, ability to learn, dexterity, and innovativeness (6). Rogers (42) recognizes that highly innovative executives aggressively thrive on innovation and often rely on knowledge and experience to advantageously steer up the organization in times of uncertainty. Educated CEOs are more cosmopolitan in their social relation-ships, more informed about value creation, more exposed to mass media, show less group cohesiveness, and are more likely to obtain information from scientific sources and experts. They have a greater tendency to learn about an innovation and to diffuse its benefits to others. Conversely, executives with weak education often exhibit high levels of risk aversion because they feel threatened by change and only invest after first-mover advantages may have been lost.

\section{The Moderators}

Traditionally, location and central place experts use mainly geographical factors to develop conceptual frameworks that guide the design of optimally positioned facilities/networks; they analyze spatial structure of a business or the complexity of firms in one or more geographical areas. With the world turning flat, one attempts to de-emphasize distance (geographical locations) and size barriers of the traditional theories of location and central place experts. ICT infrastructures assist SMEs located in remote areas to improve geographic proximity and to overcome communications ordeals placed by their physical distance, though studies $(47,29)$ report that SMEs tend to adopt ICT solutions very sluggishly. The probability of adopting innovative concepts within a region correlates with the range and quality of resources located therein. Wever and Stam (60) distinguished between classical resources munificence theory and the learning economy approach.

The first proposes that some geographic areas have a more favourable location and resource advantages than others in terms of a better educated and diverse workforce, better knowledge centres, more venture capital companies, and more quality services. Urban and localization economies within the classical munificence theory provide further insights; urban economies arise from urban concentration and include such external factors as availability of diverse workforce, physical infrastructures, and a range of diversified activities. Scholars $(50,33)$ propose that access to a pool of diverse labour permits the transmission of new practices for managing inter-firm relations as well as technical information and access to suppliers of new technologies and consultants that assist firms to make informed technology decisions. Localization economies refer to the degree of industrial specialization (e.g., natural and created endowments, dedicated suppliers, and other specialized inputs) within a locality. Studies $(14,44)$ proposed that spatial proximity (perhaps induced by location-specific advantages) of industrial activities (perhaps amongst similar firms) promotes a network of knowledge externalities within a locality. The learning economy approach, on the other hand, proposes innovation as a process of interaction in the value-chain. The geo-graphic proximity and the institutional framework encourage interaction that will cause the formation of regional clusters of innovative activities (50). These theories suggest that there is a positive relationship between ICT adoption and population density with the association increasing as the technical complexity of ICTs increases.

\section{Research Strategy}

Opinions of owners/managers were purposefully sampled from registered SMEs in five industries (furniture, cybercafés, superstores, printing and publishing, and electronics and home appliances) of the South-east, South-west, and South-south geo-political zones of Nigeria. A sample size of 344 was drawn using Krejcie and Morgan's (31) table as a guide. Two cities (a state capital and industrial/commercial nerve centre) known overtime to (a) differ in terms of their socio-economic and socio-political strides, and (b) to play significant host to commercial activities were the tar-get(s). For instance, Port Harcourt and Warri were selected from the South-south; Lagos and Ijebu Ode from the South-west; and Enugu and Aba from the South-east. Studying these cities guided testing location differences as captured in $\mathrm{H} 5 \mathrm{a}$ and $\mathrm{H} 5 \mathrm{~b}$. The questionnaire was designed to reflect structured disguised and structured-undisguised questions as well as mandatory and optional questions; and sampling was based on predetermined benchmarks (1) defining SMEs in terms of having not more than 20 workers, (2) having owner(s) directly involved in the management, and (3) exploiting the potentials of network externalities. Aside from Lagos which attracted 75 copies of the questionnaire because of its stronger socio-economic and socio-political strengths, other state capitals got 70 copies; and the commercial nerve centres were treated as being equal (Table 1). The questionnaire was accompanied by a cover letter, which assured respondents of confidentiality of any information provided. However, the response rate was 193 (56.11\%).

Table 1. Descriptive statistics

\begin{tabular}{|c|c|c|c|}
\hline City & $\begin{array}{c}\text { Copies of } \\
\text { ques-tionnaires } \\
\text { ad-ministered }\end{array}$ & $\begin{array}{c}\text { Copies of } \\
\text { ques-tionnaires } \\
\text { re-turned }\end{array}$ & $\begin{array}{c}\text { Percentage } \\
\text { of returns }\end{array}$ \\
\hline $\begin{array}{c}\text { Port } \\
\text { Harcourt }\end{array}$ & 70 & 37 & 10.76 \\
\hline Warri & 43 & 19 & 5.52 \\
\hline Enugu & 70 & 41 & 11.92 \\
\hline Aba & 43 & 28 & 8.14 \\
\hline Lagos & 75 & 46 & 13.37 \\
\hline Ijebu-ode & 43 & 22 & 6.40 \\
\hline Total & 344 & 193 & 56.11 \\
\hline
\end{tabular}




\section{Measures}

The intra-firm and inter-firm adoptions are often the main focus of this kind of study (5). The former perceives adoption as a part of business strategy within a firm; and for the latter, adoption integrates firms. This study takes the latter approach as it measures ICT adoption by the extent to which inter-firm (SMEs and trading partners) integration of operations, procedures, and processes improves customer service, inventory management, and cost reduction. Statement items were developed based on the hypotheses to reflect the definitions of variables, outcomes of preliminary study, and objectives of the study. The scale for location reflected statement items that bordered on how the relationship between top management composition and ICT adoption is shaped by diverse workforce and knowledge centres. These two location factors were chosen based on the peculiarities of Nigeria in terms of developmental strides and minerals' de-posit that inform varying concentration of industrial activities. Specifically, diverse workforce was measured by (1) access to pool of qualified and diverse ICT labour, (2) knowledge spill-over and knowledge transfer, and (3) experience to manage the technical complexities of new technology in maintaining inter-firm relations. Knowledge centres measure how institutional framework and policies stimulate inter-and intra-firm interactions, knowledge sharing, and cluster of innovative ideas (see 50).

A Likert-scale items was developed to measure ICT adoption rate and the influence of location factors, and the responses range from (1) "don't agree at all" to (5) "completely agree." Age was measured by one statement item involving years (nominal data); adult defines those above 40. Gender is self explanatory (11) and also involved one statement item; nominal scale ( 1 if male and 0 if otherwise). Experience measures career consistency (in ICT firms) on a scale spanning less than 5 years, between 5 and 10 years, etc. Education measures academic attainment of the respondents as shown in the scale developed by Awa et al. (4):

- First School Leaving Certificate (FSLC),

- Junior Secondary Certificate Examinations (JSCE),

- Senior Secondary Certificate Examinations (SSCE) or equivalents (WASC and GCE),

- National Diploma or its equivalent,

- B.Sc, B.Tech, B.A, Higher National Diploma (HND),

- Post-graduate degrees, and

- Professionals without degrees/HND

Although previous studies $(29,11,46)$ directly or indirectly confirmed the content validity of some of these scale items, the items were further subjected to face validity involving the scrutiny of informed persons in order to en-sure that the statements framed up appropriately and internally represent the property measured. Further, a pilot study of 12 subjects was conducted to pre-test the scale items on limited sampling units in order to improve simplicity and consistency before the actual study.

\section{Data Analysis and Presentation}

This paper identifies how diversified workforce and knowledge centres moderate the relationship between the demographic composition of top management and ICT adoption. A four-step hierarchical regression procedure was used to analyze the data. The exercise involved (1) factor-loading of the independent variables, (2) loading of the direct effects, then (3) the moderator, and (4) the interaction effects. Since some nominal data were collected, SPSS procedure converted them to interval to permit the use of regressions. The model summary (see Table 2) showed that under the moderating influence of location factors, the predictor variables explained an overall estimate of 27 percent variations of ICT adoption behaviour (see $\mathrm{R}^{2}=0.271$, $\mathrm{p}<0.01$ ). Thus, managerial characteristics of key actors are largely a function of demographic and location factors and both directly influence the adoption of ICT. When the model variables were loaded, the additional variance explained stood at 1.13 percent and $\mathrm{F}$ change of $3.88, \mathrm{p}<0.01$. All the demographic factors loaded into the model equation showed statistical inter-action with ICT adoption, thereby lending support to $\mathrm{H} 1-\mathrm{H} 4$. See age $(\beta=0.255, \mathrm{p}<0.05)$, gender $(\beta=$ $0.213, \mathrm{p}<0.05)$, experience $(\beta=0.234, \mathrm{p}<0.05)$ and education $(\beta=0.224, p<0.05)$.

When the location factors were loaded against age, their interactions were statistically significant (see $\beta=0.413, p<$ $0.05 a ; \beta=0.322, p<0.05 b)$. This suggests that the relationship between the age bracket of members of top management and adoption of ICT is shaped by location factors; with $\beta=0.272, p<0.05$, executives of less than 40 are major adopters. Further, factoring location factors against experience, their interactions were statistically significant (see $\beta=0.223, p<0.05 a ; \beta=0.217, p<0.05 b$ ). It was evidenced that top management made up of executives with at least 5 years of experience were critical in the adoption. When the location factors were factored against gender, their interactions were still statistically significant $(\beta=0.214, p<$ $0.05 \mathrm{a} ; \beta=0.311, \mathrm{p}<0.05 \mathrm{~b})$. Finally, when the location factors were measured against education, positive statistical interactions unveiled; B.Sc./HND and above $(\beta=0.204$, $\mathrm{p}<$ 0.05 ) showed a significant positive relationship with ICT adoption. The location factors brought in an incremental variance of 15 percent and when the interaction items were loaded, the incremental variance became 32 percent. The $\mathrm{F}$ change statistics of 3.05 for model 3 and 4.06 for model 4 were significant. 
Table 2. Hierarchical Regression Analysis

\begin{tabular}{|c|c|c|c|c|}
\hline Independent Variable & $\begin{array}{l}\text { Std. Beta stage1 } \\
\text { (Model 1) }\end{array}$ & $\begin{array}{l}\text { Std. Beta stage2 } \\
\text { (Model 2) }\end{array}$ & $\begin{array}{c}\text { Std. Beta } \\
\text { stage3 } \\
\text { (Model 3) } \\
\end{array}$ & $\begin{array}{c}\text { Std. Beta } \\
\text { stage } 4 \\
\text { (Model 4) }\end{array}$ \\
\hline Age & $0.255^{*}$ & $0.212 * *$ & $0.281 * *$ & $0.224 *$ \\
\hline Gender & $0.213^{*}$ & -0.193 & $-0.156^{*}$ & $0.242 *$ \\
\hline Experience & $0.234 *$ & 0.423 & $0.201 *$ & $0.253^{*}$ \\
\hline Education & $0.224 *$ & 0.453 & 0.123 & $0.214 *$ \\
\hline 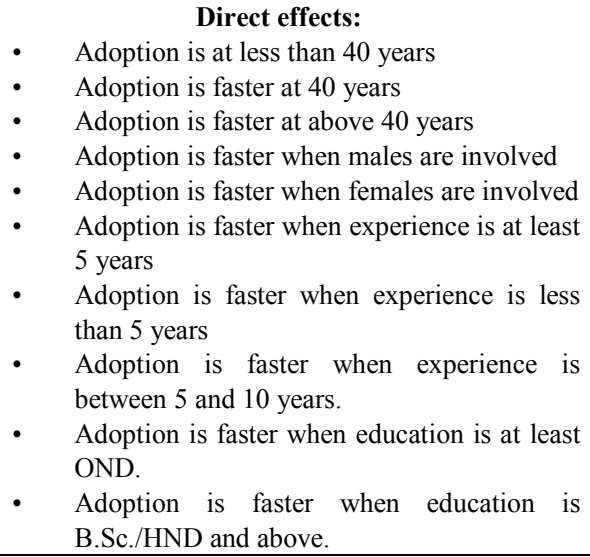 & $\begin{array}{c}0.272^{*} \\
0.423 \\
0.231\end{array}$ & $\begin{array}{c}0.263^{*} \\
0.285\end{array}$ & $\begin{array}{c}0.265^{*} \\
0.244 \\
0.431\end{array}$ & $\begin{array}{c}0.234 \\
0.204^{*}\end{array}$ \\
\hline $\begin{array}{l}\text { Moderating Variables: } \\
\text { a. diversified workforce } \\
\text { b. knowledge centres }\end{array}$ & & & $\begin{array}{l}0.021 \\
0.065 \\
\end{array}$ & $\begin{array}{l}0.280^{*} \\
0.234^{*}\end{array}$ \\
\hline \begin{tabular}{ll} 
& \multicolumn{1}{c}{ Interactive effects: } \\
- & Age and diversified workforce \\
- & Age and knowledge centres \\
- & Experience and diversified workforce \\
- & Experience and knowledge centres \\
- & Education and diversified workforce \\
- & Gender and diversified workforce \\
- & Gender and knowledge centres \\
\end{tabular} & & & & $\begin{array}{l}0.413^{*} \\
0.322^{*} \\
0.223^{*} \\
0.217^{*} \\
0.210^{*} \\
0.312^{*} \\
0.214^{*} \\
0.311^{*}\end{array}$ \\
\hline \multicolumn{5}{|l|}{ Model Summary } \\
\hline $\mathrm{R}$ & 0.521 & 0.554 & & 0.602 \\
\hline $\mathrm{R}^{2}$ & 0.271 & 0.310 & & 0.362 \\
\hline Adjust $\mathrm{R}^{2}$ & 0.227 & 0.272 & 0.256 & 0.226 \\
\hline $\mathrm{R}^{2}$ change & - & 0.045 & 0.016 & 0.030 \\
\hline F change & - & $3.51 * *$ & $0.305^{* *}$ & $0.406^{* *}$ \\
\hline
\end{tabular}

Note $* \mathrm{p}<0.05 ; * * \mathrm{p}<0.01$

\section{Discussion}

ICT and its infrastructures are associated with socio-economic developments and operational efficiency. This paper studied how knowledge centres and diverse workforce moderate the relation-ship between the demographic composition of top management and ICT adoption. We discussed the relationships between the demographic constructs and ICT adoption, and then proceeded to see how such relationships were shaped by the moderator variables. The equation found that age has significant positive relationship with ICT adoption. While this confirms other studies $(4,8,22)$, which show the significant role of younger executives in adoption decision; it somewhat contradicts others (e.g., 11) that assume age has a significant negative effect on ICT adoption. One possible explanation to this contradiction is that ICT adoption cuts across ages in the developed nations; whereas in some developing nations, adoption is faster amongst younger executives who often exploit its platforms to build competitive advantage. When the location factors were loaded against age, their interactions were statistically significant ( see $\beta=0.413, \mathrm{p}<0.05 \mathrm{a} ; \beta=0.322, \mathrm{p}<0.05 \mathrm{~b}$ ). This suggests that the relationship between the age bracket of members of top management and adoption of ICT is shaped by location factors; with $\beta=0.272, p<0.05$, executives of less than 40 are major adopters.

While this age bracket concentrates more in the cities (see $56)$, studies $(7,9,22,44,11)$ pro-pose that age has a lot to do in the strategic and proactive mindsets of top executives in 
dealing with the competitive states of nature that greet related activities in proximity. ICT-related experiences of top management were critical in determining ICT adoption. This finding underscores previous studies $(19,58,43,11,29$, $51,23)$ that found that top management's internet-use experiences, skills, and practices intensify adoption. Appreciation of the potentials of ICT platforms is directly connected to the CEOs' learning and experience curves, which undoubtedly minimize the complexities of an untried innovation. When the location factors were measured against experience, their interactions were statistically significant (see $\beta=0.223, p<0.05 a ; \beta=0.217, p<0.05 b$ ). Further, top management made up of executives with at least 5 years of experience is critical in the adoption. Previous studies (22, $53,15,46)$ found that managerial experience about the state of nature explains the propensity to understand and adopt innovations that are more competitive.

Gender has a significant positive correlation coefficient with ICT adoption and the value for males was statistically significant (see $(\beta=0.214, p<0.05 a ; \beta=0.311, p<0.05 b)$. This finding is consistent with similar studies $(20 ; 27 ; 4)$ that found statistical interaction between e-commerce adoption and gender, though Igbaria et al. (1998 53) assume that different genders have different uses for ICT; males and females use more of productivity and application packages respectively. When the location factors were factored in, their interactions were still statistically significant. Finally, education attracted a significant positive correlation coefficient with ICT adoption. Though, this contradicts Dwivedi and Lal (15) and Chuang et al. (11), amongst others, it is consistent with some others $(4 ; 10)$. Choudrie and Dwivedi (10) studied broadband use within households and reported that ICT adoption amongst a variety of firms is influenced by top management's knowledge of it benefits and the firm's expectations rather than educational attainment of the decision-makers. When the location factors were measured against education, positive statistical interactions was found.

\section{Conclusion and Implications}

Geographical locations differ in terms of the opportunities they offer different young, educated, and experienced labour force, which ultimately define extent of innovation adoption in a system. Factoring in location factors suggest that diversified workforce and knowledge centres have direct influence on top management's demographic composition and ICT adoption. SMEs located far from the cities tend to adopt ICT solutions very sluggishly because the range and quality of avail-able resources seldom encourage adequate adoption. Somuyiwa and Adewoye (47) propose that SMEs need quality resources to improve geographic proximity and to overcome communications ordeals placed by their size and physical distance. On the recognition that corporate directions and dynamics are largely a product of cognitive perceptions and assumptions of key actors, this paper studied how the relationship between the demographic composition of top management and ICT adoption is moderated by location factors.

Evidence from the study led to the conclusion that availability of diversified workforce and knowledge centres statistically moderate age, gender, education, and experience composition of top management and ultimately ICT adoption. Thus, ICT is yet to achieve its target in some economies because the infrastructural facilities are not evenly distributed and so, some cities play stronger host than others. Four implications are proposed. First, government and its agencies should spread the facilitating and developmental infrastructures evenly to de-emphasize rural-urban migration and encourage SMEs exploit the full potentials of ICT irrespective of their locations. Second, SMEs should recognize the differences in the adoption and demographic composition of top management as spelt by location factors and tailor decisions accordingly. Third, staffs' learning and experience curves should be constantly updated by creating an environment that allows for training and retraining in order to unfold more opportunities within and beyond a location. Finally, service providers should increase the switching costs by improving upon ICT infra-structures to a level where location factors and demographic composition of management team will rarely be adoption barriers, especially amongst developing economies.

\section{REFERENCES}

[1] Albaladejo-Pina, I. and Díaz-Delfa, M. "Tourist preferences for rural house stays: Evidence from discrete choice modeling in Spain," Tourism Management, 2009, 30(6), 805-811.

[2] Alutto, J. and Hrebiniak, L. Research on commitment to employing organizations: Preliminary findings on a study of managers graduating from engineering and $M B A$ programmes. Paper Presented at Academy of Management Meetings, 1975, New Orleans.

[3] Apulu, I., Latham, A. and Moreton, R. "Factors affecting the effective utilization and adoption of sophisticated ICT solution: Case studies of SMEs in Lagos, Nigeria," Journal of Systems and Information Technology, 2011, 13(2), 125-143.

[4] Awa, H., Eze, S., Urieto, J. and Inyang, B. "Upper echelon theory: A major determinant of information technology (IT) adoption by SMEs in Nigeria," Journal of Systems and Information Technology, 2011 13(2), 144-162.

[5] Battisti, G. and Stoneman, P. "Inter- and intra-firm effects in the diffusion of new process technology," Research Policy, 2003, 32(9), 1641-1655.

[6] Becker, H. "Socio-metric location and innovativeness: Reformulation and extension of the diffusion model," American Sociological Review, 1970, 35, 267-303.

[7] Carlsson, G. and Karlsson, K. "Age, cohorts and the generation of generations," American Sociological Review, $1970,35,710-718$. 
[8] Chau, P. "Re-examining a model for evaluating information centre success using a structural equation modeling approach," Decision Sciences, 1997, 28, 309-34.

[9] Child, J. "Managerial and organizational factors associated with company performance," Journal of Management Studies, 1974, 11, 13-27.

[10] Choudrie, J. and Dwivedi, Y. "The demographics of broadband residential consumers in British local community: The London Borough of Hillingdon," Journal of Computer Information Systems, 2005, 45(4), 93-101.

[11] Chuang, T., Nakatani, K. and Zhou, D. "An exploratory study of the extent of information technology adoption in SMEs: An application of upper echelon theory," Journal of Enterprise Information Management, 2009, 22(1/2), 183-196.

[12] Davis, F. "Perceived usefulness, perceived ease of use, and user acceptance of information technology," MIS Quarterly, 1989, 13(3), 319-340.

[13] Den Hoogen, I. "Early adopters and power users," Forbes/INSIGHTS, 2010, 9-11.

[14] de Noronha Vaz, T., Morgan, E. and Nijkamp, P. The New European rurality: Strategies for small firms, 2006, Aldershot: Ashgate Publishing.

[15] Dwivedi, Y. and Lal, B. "Socio-economic determinants of broadband adoption," Industrial Management and Data Systems, 2007, 107(5), 654-671.

[16] Federici, T. "Factors influencing ERP outcomes in SMEs: A post-introduction assessment," Journal of Enterprise Information Management, 2009, 22(1/2), 81-98.

[17] Fills, I., Johanson, U. and Wagner, B. “A conceptualization of opportunities and barriers to e-business development in the small firms," Journal of Small Business and Enterprise Development, 2003, 10(1), 336-344.

[18] Fiske, S. Schema-triggered affect: Applications to social perception. In M. Clark \& S. Fiske (eds.), Affect and Cognition: The 17th Annual Carnegie Symposium on Cognition. Hillsdale, New Jersey: Lawrence Erlbaum Associates, 1982, 55-78.

[19] Galloway, L. and Mochrie, R. "The use of ICT in rural firms: A policy -oriented literature review," Info, 2005, 7(3), 33-46.

[20] Gefen, D. and Straub, D. "Gender difference in the perception and use of e-mail: An extension to the technology acceptance model," MIS Quarterly, 1997, 21(4), 389-400.

[21] Glover, M. "Reaching executives through mobile adv.," Forbes/INSIGHTS, 2010, 12-13.

[22] Hambrick, D. and Mason, P. "Upper echelons: The organization as a reflection of its top managers," Academy of Management Review, 1984, 9(2), 193-205.

[23] Hashim, J. Information communication technology (ICT) adoption among SMEs owners in Malaysia. The International Journal of Business and Information, 2007, 2, 221-240.

[24] Hedges, M. “The need to be nimble," Forbes/INSIGHTS, 2010, 6-8.

[25] Heilbrun, A. "Measurement of masculine and feminine sex role identities as independent dimensions," Journal of Consulting and Clinical Psychology, 1976, 44, 183-190.
[26] Iacovou, C., Benbasat, I. and Dexter, A. "Electronic data interchange and small organization: Adoption and impact of technology," MIS Quarterly, 1995, 465-485.

[27] Jimme, J. and Mukhopadhyay, S. "A bi-national examination of gender and IT adoption," International Journal of Society Systems Science, 2010, 2(3), 255-268.

[28] Justice, C. “A more mobile future,” Forbes/INSIGHTS, 2010, 14-15.

[29] Kannabiran, G. and Dharmalingam, P. "Enablers and inhibitors of advanced information technologies adoption by SMEs: An empirical study of auto ancillaries in India," Journal of Enterprise Information Management, 2012, 25(2), 186-209.

[30] Kisusu, R. Adoption and impact of diary and irrigation rice technologies on poverty alleviation in Dodoma, Tanzania.' Ph.D thesis, 2003, Sokoine University of Agriculture, Morogoro, p. 185.

[31] Krejcie and Morgan (1970) in Sekaran, U. (2003). Research methods for business, New York: John Wiley \& Sons.

[32] Lefebvre L., Harvey, J. and Lefebvre, E. "Technological experience and the technology adoption decisions in small manufacturing firms," $R \& D$ Management, 1991, 21(3), 241249.

[33] Morgan, K. “The learning region, institutions, innovations and regional renewal," Regional Studies, 1997, 31, 491-503.

[34] Muuka, G. “Africa's informal sector matters: A challenge to scholar to close the knowledge gap," Proceedings of Academy of African Business and Development International Conference, Port Eliza-beth, April 3-6, 2002, pp1-6.

[35] Mutuala, S., \& Brakel, P. "E-readiness of SMEs in the ICT sector in Botswana with respect to Information Access," The Electronic Library, 2006, 24(3), 402-427.

[36] Ogechukwu, A. The role of small scale industry in national development in Nigeria. A paper pre-sented at Association for Small Business and Entrepreneurship Annual Conference, Corpus Christi, TX, 1-3 Nov., 2006.

[37] Ojukwu, D. and Georgiadou, E. Toward improving inter-organizational trust amongst SMEs: A case study from developing countries. Proceedings of the 9th International Conference on Social Implications of Computers in Developing Countries, Sao Paulo, Brazil, 2007.

[38] Oladele, O. "A tobit analysis of propensity of discontinue adoption agricultural technology among farmers in South-western, Nigeria," Journal of Central European Agriculture, 2005, 6(3), 249-254.

[39] Ongori, H. and Migrio, S. "Information and communication technology adoption: A literature review," Journal of Chinese Entrepreneurship, 2010, 2, 93-104.

[40] Ongori, H. "Role of information communication technologies adoption in SMEs: Evidence from Botswana," Research Journal of Information Technology, 2009, 1(2), 93-104.

[41] Riemenschneider, C. and Mckinney, V. "Assessing belief differences in small business adopters and non-adopters of web-based e-commerce," Journal of Computer Information Systems, 2002, 42(2), 101-107.

[42] Rogers, E. (1995). Diffusion of innovations (4th ed.). New 
York: The Free Press.

[43] Sabherwal, R., Jeyaraji, A. and Chowa, C. "Information systems success: Individual and organizational determinants," Management Science, 2006, 52(12), 849- 864.

[44] Saxenian, A. Regional advantage. Cambridge MA: Harvard University Press, 1994.

[45] Scupola, A. "SMEs' e-commerce adoption: Perspectives from Denmark and Australia," Journal of Enterprise Information Management, 2009, 22(1/2), 152-166.

[46] Shiau W., Hsu P. and Wang, J. "Development of measures to assess the ERP adoption of small and medium enterprises," Journal of Enterprise Information Management, 2009, 22(1/2), 99-118.

[47] Somuyiwa, A. and Adewoye, J. "On managing logistics information systems: Theoretical underpinning," Asian Journal of Business Management, Maxwell Scientific Organization, 2010, 2, 41-47.

[48] Spry Foundation, Older adults and the world wide web. http://www.spry.org 2005.

[49] Ssewanyana, J. "ICT usage in microfinance institution in Uganda," The African Journal of Information Systems, 2009, $1(3), 5-28$.

[50] Storper, M. "The resurgence of regional economics, ten years later: The region as a nexus of untraded interdependencies," European and Urban Regional Studies, 1995, 191-221.

[51] Tan, K., Chong, S. and Eze, U. "Internet-based ICT adoption: Evidence from Malaysia SMEs," Industrial Management \& Data Systems, 2009, 109, 224-244.

[52] Target Group Index Europa Survey. (2000).

[53] Thong, J. "An integrated model of information systems adoption in small businesses," Journal of Management Information Systems, 1999, 15(4), 27-31.
[54] Thorndike, R. Research problems and techniques. Washington: U.S. Government Printing Office. Report No. 3 AAF Aviation Psychology Programme, 1947.

[55] Tornatzky, L. and Fleischer, M. The process of technology innovation, Lexington, M.A: Lexington Books, 1990.

[56] Uzor, B. "Low-income group seen as drivers of sustainable e-commerce growth in Nigeria," Business Day, 6-8 September, 2013, p. 4.

[57] Valdés, L. El turismo rural en España, In A. Pedreño Muñoz \& V. M. Monfort Mir (Eds.). Intro-ducción a la economía del turismo en España, Civitas, Madrid, 1996.

[58] Wainwright, D., Green, G., Mitchell, E., and Yarrow, D. "Toward a framework for benchmarking ICT practice, competence, and performance in small firms."The International Journal for Library and In-formation Services, 2005, 6, 39-52.

[59] Wetengere, K. "Socio-economic factors critical for adoption of fish farming technology: The case of selected villages in Eastern Tanzania," International Journal of Fisheries and Aquaculture, 2008, 1(3), 28-37.

[60] Wever, E. and Stam, E. "Clusters of high technology SMEs: The Dutch case," Regional Studies, 1999, 33(4), 391-400.

[61] Windrum, P. and de Berranger, P. "Factors affecting the adoption of intranets and extranets by SMEs: A UK study," Working paper, MERIT, Maastricht Economic Research Institute on Innovation and Technology, Maastricht, 2003.

[62] Wright, P. "Consumer choice strategies: Simplifying vs. optimizing," Journal of Marketing Research, 1975, 11(Feb.), 60-67.

[63] Zhu K., Kraemer K. and Xu, S. "Electronic business adoption by European firms: A cross -country assessment of the facilitators and inhibitors," European Journal of Information Systems, 2003, 12(1), 1-21. 